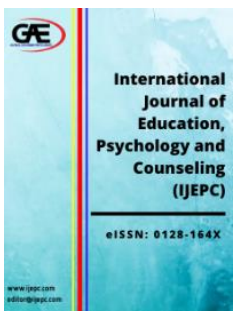

\author{
INTERNATIONAL JOURNAL OF \\ EDUCATION, PSYCHOLOGY \\ AND COUNSELLING \\ (IJEPC) \\ www.ijepc.com
}

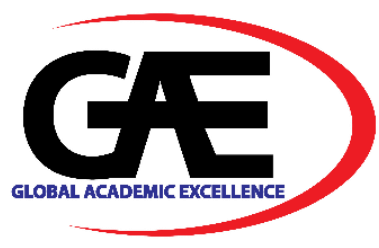

\title{
CAMPUS SUSTAINABILITY: MEASURING AWARENESS OF SUSTAINABLE DEVELOPMENT DIMENSIONS AMONG EDUCATORS IN MALAYSIAN UNIVERSITY
}

\author{
Sharmila Rani Moganadas ${ }^{1 *}$, Subhacini Subramaniam ${ }^{2}$, Nun Shwu Huey ${ }^{3}$, Ainee Suriani Bahaman ${ }^{4}$ \\ 1 Faculty of Business, Multimedia University, Melaka, Malaysia \\ Email: sharmila.rani@mmu.edu.my \\ 2 Faculty of Business, Multimedia University, Melaka, Malaysia \\ Faculty of Business, Multimedia University, Melaka, Malaysia \\ Faculty of Science and Information Technology, Multimedia University, Melaka, Malaysia \\ Corresponding Author
}

\section{Article Info:}

Article history:

Received date: 13.07 .2020

Revised date: 10.08 .2020

Accepted date: 30.09 .2020

Published date: 01.12.2020

\section{To cite this document:}

Moganadas, S. R., Subramaniam, S., Nun, S. H., \& Bahaman, A. S. (2020). Campus Sustainability: Measuring Awareness of Sustainable Development Dimensions among Educators in Malaysian University. International Journal of Education, Psychology and Counseling, 5 (37), 10-26.

\section{DOI: $10.35631 / \mathrm{IJEPC} .537002$.}

This work is licensed under CC BY 4.0

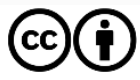

\section{Abstract:}

Sustainable development has long gained momentum as an indispensable change-maker of the present and future, across nations, organisations, institutions, and individuals around the globe. Despite its universal recognition, the understanding of the concept's constituents seems vague and heterogeneous, which has led to piecemeal initiatives that appear to impede the vision of systemic sustainability. In this disposition, many experts reckon that the higher education institutions that are in the sustainably adept nick, capable of cultivating and leading the community towards a holistic sustainable development approach. This portrays the need for a sound knowledge or awareness of sustainable development dimensions among campus actors; in particular, the educators, as it emerges as the prerequisite to campus sustainability endeavours. This paper, therefore, aims to carry out one of the grassroots level efforts, which is to measure the awareness of sustainable development dimensions among academic staff of a private university in Malaysia. This research adopted an online and offline survey to obtain responses from 169 educators. The findings show that there are significant differences in the level of awareness on sustainable development dimensions (economy, social, and environment) among educators of the university. Gaps and needs identified in this study can be useful to the management to better orientate their actions towards campus sustainability plans, such as policies, curriculum development, operations, research, etc. 
Keywords:

Awareness, Economy, Educators, Environment, Higher Education Institutions, Social, Sustainable Development

\section{Introduction}

Sustainable development adage is becoming increasingly prominent, mainly with the 2030 Agenda for Sustainable Development, which includes 17 Sustainable Development Goals (SDGs) (United Nations, 2015). While advocating the doctrine of "leaving no one behind," the Agenda reaffirms the need for a holistic approach in the implementation of sustainability throughout the world in the ambits of economic well-being, environmental standards as well as social relations (Böhringer \& Jochem, 2007; United Nations, 2018). As a response, major stakeholders, like businesses, institutions and individuals across nations are urged to adopt inclusive sustainability policies, strategies and practices that focus beyond the environmental prefecture (Fisher \& McAdams, 2015).

To achieve this, many scholars agree that tertiary institutions are the main synergists that are capable of edifying and transmuting the current and forthcoming generations through their core activities such as teaching, research, campus sustainability, outreach programme, operations, governance and policies (Cortese, 2003, Velazquez, Munguia, Platt \& Taddei, 2006). In this sense, several studies put forward that sustainably conscious and adept university professionals, who are directly and indirectly involved in the planning, designing and integrating relevant initiatives (e.g. sustainable development curriculum development) are the preconditions of campus sustainability efforts and societal transformation (Lozano, Lukman, Lozano, Huisingh \& Lambrechts, 2011). In view of this, several studies concurred that a paucity of sustainability-related knowledge or awareness among campus members signifies a lack of preparedness among higher education institutions and it may deter the implementation of sustainability initiatives as a whole (Velazquez et. al., 2006; Lozano et. al., 2011).

Such circumstance clearly calls for a systematic and rudimentary approach, which is delving into campus actors' awareness on sustainable development, prior to hastening into initiatives that are more radical. Further, to the best knowledge of the authors, studies demonstrating the levels of sustainable development awareness among campus members, particularly, educators in higher education institutions are limited, especially in the context of Malaysia. This study, therefore, aims to fill in this gap, by gauging the awareness of sustainable development dimensions among educators in a Malaysian private university setting.

\section{Literature Review}

\section{Sustainable Development Theories and Dimensions}

The Brundtland Report, or often recognised as Our Common Future emphasised three fundamental constituents for sustainable development: environmental protection, social equity and economic growth. Subsequently, in 1995, the World Bank produced a complete report, titled, Defining and Measuring Sustainability, which elucidated the meaning and applications of sustainability across diverse disciplines, as well as disclosing the inherent definition of sustainability as "people-centred" concept (Munasinghe \& Shearer, 1995). In addition, Sustainable Development - key elements and interconnections (corners, sides, centre) Triangle (as depicted in Figure 1), that prescribed approaches to sustainable development, appeared to Copyright $\odot$ GLOBAL ACADEMIC EXCELLENCE (M) SDN BHD - All rights reserved 


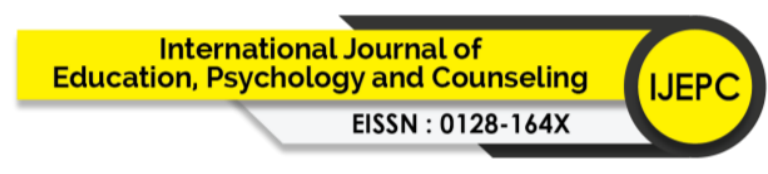

Volume 5 Issue 37 (December 2020) PP. 10-26

DOI 10.35631/IJEPC.537002

be one of the important elements of the report. The triangle demonstrated a way of achieving sustainability via three different but reciprocal dimensions enunciated as follows: economic which seeks to preserve production capabilities and maximise income, whilst maintaining capital stock; an environment that emphasises the integrity of biological-physical systems that compromise natural capital; and the sociocultural that comprises of equity and participation (Munasinghe \& Shearer, 1995). Another model that resonates with this credence is the Egg of Sustainability model, which was developed by the Conservation of Nature (IUCN) in 1994 (Centre for Environment Education, 2007). It explained that social and economic developments would continue to thrive as long as the environment is able to offer the necessary resources. This obviously calls for a prolonged continuance of the environmental constituents.

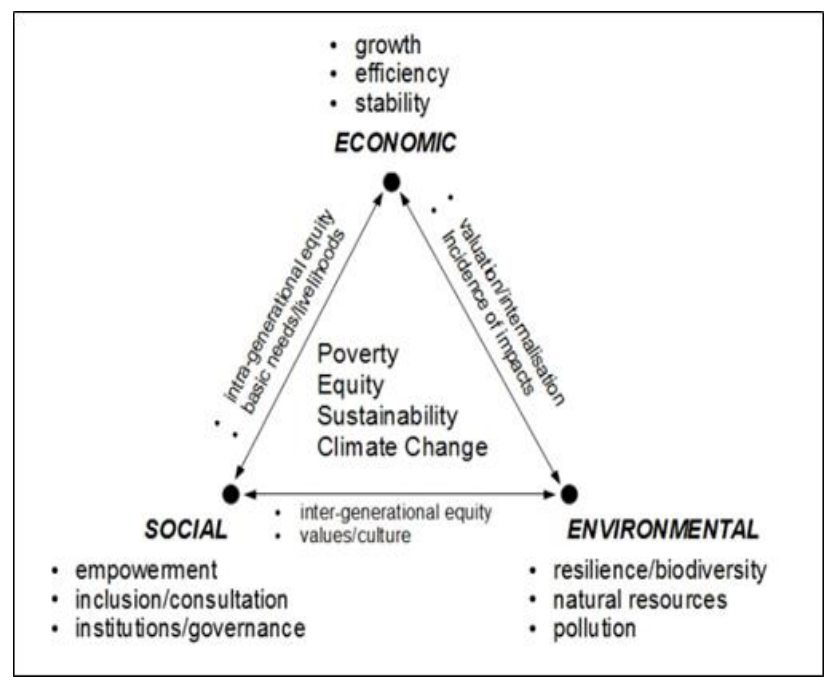

Figure 1 Sustainable Development - Key Elements and Interconnections (Corners, Sides, Centre) Triangle

(Adapted from Sustainomics Framework (p. 36), by M. Munasinghe, 2010, Sri Lanka: MIND Press. Copyright 2010 by MIND Press)

In the context of the "three-pillar" paradigm, Purvis, Mao and Robinson (2019) construed two subtle differences pertinent to the conceptualisation of the pillars. The initial approach presents individual dimensions as distinct "(biological and other resources, economic and social), yet interacting systems," (Purvis et al., 2019, p.689) and the latter, infers them as three different dimensions (social, ecological and economic), having "interrelated perspectives" (Purvis et al., 2019, p.689). The authors further posited that this configuration demonstrates a lack of commonality in how relationships between the dimensions are treated, whether with the presence of trade-offs or mutual reinforcements (Purvis et al., 2019). The dimensions are usually illustrated in the form of three intersecting circles (or Venn diagram) of society, environment, and economy, with sustainability located at the intersection (as depicted in Figure 2). Other similar manifestations of these aspects include nested concentric circles and literal 'pillars' that are also depicted visually. Although simple in nature, some scholars reckoned the meaning conveyed by these diagrams is often ambiguous, thus impeding the ability to operationalise coherently (Purvis et al., 2019). 
Volume 5 Issue 37 (December 2020) PP. 10-26

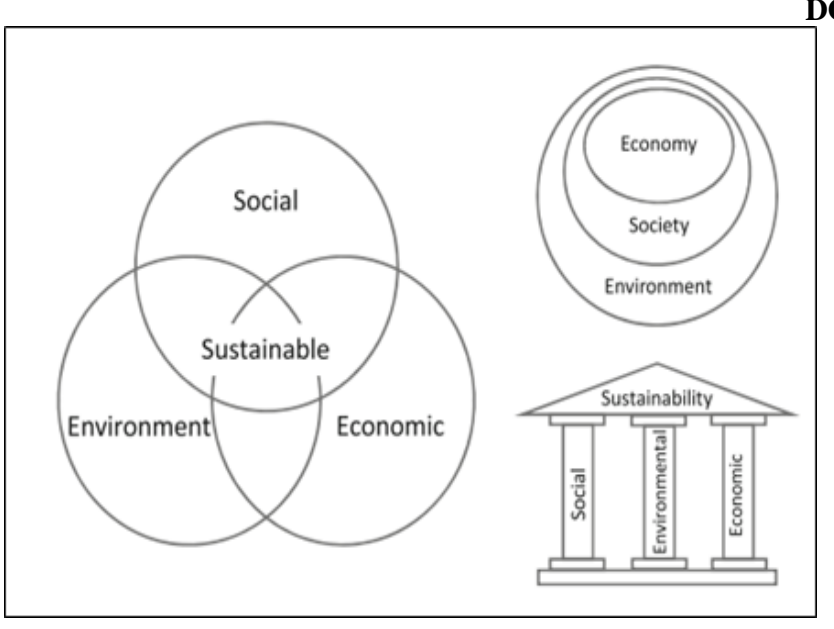

DOI 10.35631/IJEPC.537002

(Adapted from Purvis et al., 2019)

Figure 2 Depictions of Three-Pillar Diagrams

Alternatively, John Elkington transformed the three pillars concept into Triple Bottom Line (TBL), a more business-oriented framework, which gained popularity in the late 1990s, through the book, entitled, Cannibals with Forks. While similar in notion with the three pillars, this framework encourages firms to focus on decision making in business operations that increases profits and improves the planet as well as the lives of people (Elkington, 1997).

In a similar vein, some scholars viewed sustainability as maintaining and increasing the five capital stocks (natural, human, manufactured, social, and financial) that rest under the obelisks of environment, economy and society (Goodwin 2003; Kollmair \& St. Gamper 2002). Reinforcing this perspective, economist Herman Daly proposed a similar framework, known as Daly's Triangle (as depicted in Figure 3) (Dhar Chakrabarti, 2017). Ultimate means represent natural capital that is converted through science and technology to support all forms of life on the earth. Intermediate means consist of built capital that refers to the physical stock and capacities required to generate political-economic output. Next, the human capital that alludes a unique presence reflects both, intermediate means and ends. When human capital is perceived as an input (labour force) that interacts with built capital and natural materials to generate economic output, it denotes the means. On the other hand, when health and education are invested on people (human capital), they produce knowledge, public trust, tolerance, etc. that determine the social capital, which results in cohesion, participation, empowerment and institutional development. Appearing at the pinnacle of the spectrum is the ultimate ends that represent the well-being or the end goal of life that are attained through theology and ethics, comprising happiness, self-respect, etc. (Dhar Chakrabarti, 2017). Simply put, Daly's Triangle indorses sustainable development by stressing the use of means in a prudent and reasonable manner that will result in a harmony ultimate end (Lawn, 2001). 
Volume 5 Issue 37 (December 2020) PP. 10-26

DOI 10.35631/IJEPC.537002

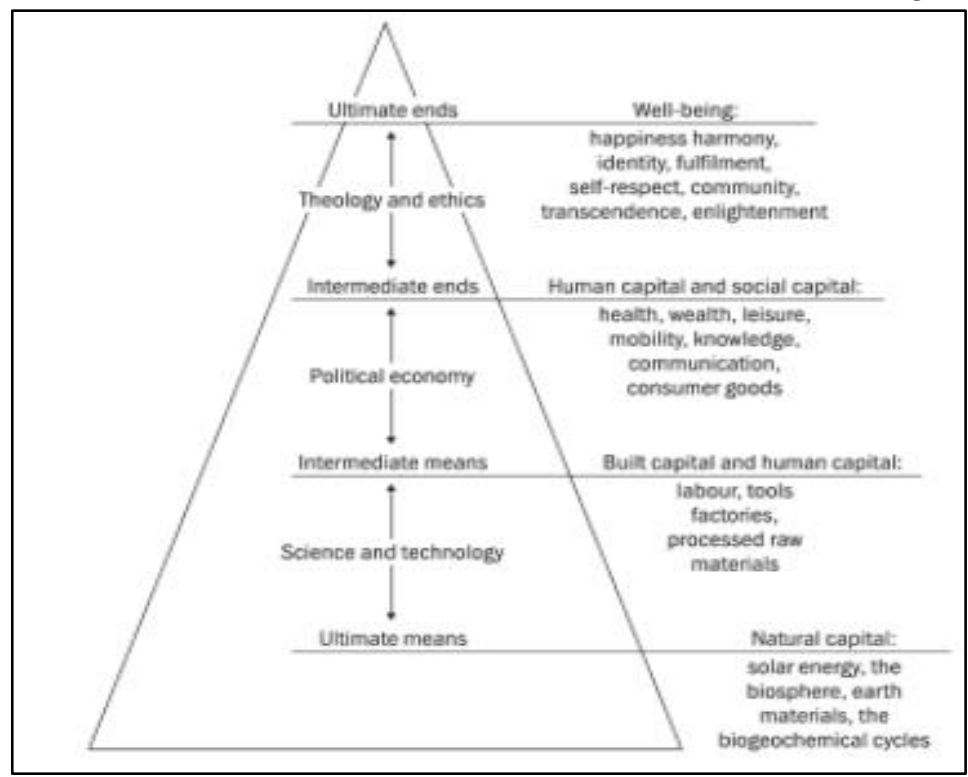

Figure 3 Daly's Triangle

(Adapted from People, Planet, and Progress Beyond 2015 (p.310), by P.G. Dhar Chakrabarti, 2017, New Delhi: The Energy and Resources Institute. Copyright 2017 by The Energy and Resources Institute)

Heinberg (2010) unswervingly corresponded with the preceding theories. The author presented five axioms of sustainability that augur the relentless use of natural and ancillary resources for human economy, imposes a caveat of inadequacy. Hence, such activity cannot prolong, and if it does, will cease at some point, resulting in societal collapse.

Based on the analysis from various theoretical lenses and literature, it is evident that a mutual relationship and interdependence present between the tripartite elements of sustainable development - meeting wider economic and social (or socio-cultural) needs, whilst limiting environmental (or ecological) impact. Nevertheless, some scholars raised their concerns on most of the existing sustainability researches that are inclined towards inquiring the environmental aspects, thus, relegating the social and economic perspectives (Cheong, 2010; Venuste, Oliviera \& Valensaas, 2017).

In essence, economic sustainability refers to the conventional use of resources, cost of living, inequality in income distribution, research and development, cost savings, sustainable production, investment in high-income sectors, responsible consumption, financial feasibility, etc. Social sustainability, on the other hand, discusses issues such as gender equality, human rights, poverty, unemployment rates, cultural diversity, education and health, peace and social justice. Lastly, environmental sustainability commonly reflects issues concerning protecting the natural resources and increasing green areas, use of renewable energy sources, reduction of environmental pollution and resource usage, recycling, carbon footprint minimisation, land use and global warming (Atmaca, Kiray \& Pehlivan, 2019; Mohd Isa, Mohd Yunos, Ismail \& Marzuki, 2018; Villeneuve, Tremblay, Riffon, Lanmafankpotin \& Bouchard, 2017). Therefore, probing into these dimensions divulge the disparate but symbiotic issues encountered worldwide, which require concomitant solutions that stem from shifts in the attitudes, behaviours and knowledge competencies (United Nations, 2015). In light of this, researchers of this study intend to adopt a balanced approach by measuring the awareness of all three sustainability dimensions among educators in a private university. 


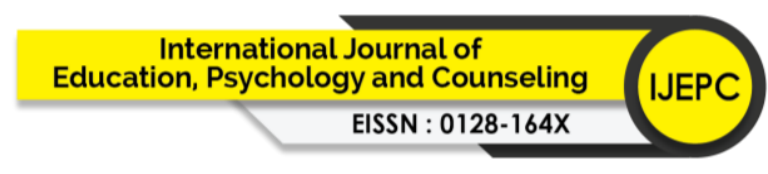

Volume 5 Issue 37 (December 2020) PP. 10-26

DOI 10.35631/IJEPC.537002

\section{Sustainable Development in Higher Education Institutions}

Sustainable development has also gained ample attention from the institutions of higher education. The inclusion of higher education sector in sustainability is evinced in several prominent treaties, charters, and partnerships such as the following (Lozano, et al., 2011; Wright, 2002; Owens, 2017; Sustainable Development Goals Knowledge Platform Website at sustainabledevelopment.un.org/index.html; Tilbury, 2011):

- The Stockholm Declaration 1972 is the first declaration to associate sustainable development with higher education in an indirect manner. Principle 19 in the statement pronounced the need for environmental education that nurtures individuals, businesses and society as a whole to protect and improve the environment.

- The Tbilisi Declaration 1977 implored universities to cogitate containing environmental and sustainability concerns within their general structure. It also recognised the requirements for a holistic approach towards sustainability initiatives amongst faculty members of a university.

- The Talloires Declaration 1990, developed by university leaders from various countries was the early official document that attempted to involve sustainability with the higher education sector, setting forth the impetus for sustainable university. It emphasised the salient role of leadership and cooperation amongst signatory universities to drive sustainability efforts.

- The Halifax Declaration 1991 emphasised the importance of universities to assume the responsibility of advocating sustainable development and addressing irrevocable environmental damages through policies and actions at local, national and global levels. Nonetheless, the findings of Wright (2002) revealed that most of the partaker universities have not executed the declaration within their institutions, whereas a few that have instigated the initiative merely used the general concepts and value statements of the declaration, instead of using it as the primary policy for the university.

- Chapter 36 in Agenda 21, established in 1992 significantly pinpointed a dearth of environmental awareness throughout the globe, and its proposed solution to curb environmentally unsustainable behaviour was through formal and informal education.

- The Kyoto Declaration 1993 aimed to develop a clearer vision for sustainable roles in universities. Aside from calling the global institutions of higher education to create specific plans of action to pursue sustainability goals through environmental education, the declaration also urged universities to adopt sustainable physical operations.

- The Swansea Declaration 1993 stressed on enhancing universities' capability to teach and carry out research in sustainable development precepts and knowledge. The treaty also called upon universities of the affluent and more developed countries to support the less wealthy nations in the implementation of sustainability.

- In 1993, the Conference of European Rectors (CRE) (presently known as Association of European Universities) developed the Copernicus Charter and presented it to its members in 1994. This charter called for a higher education sustainability statement that would be applicable to more than 500 universities within 36 countries that CRE represented. It restated the role of universities as the front-runners in forming sustainable humanities and urged for an innovative approach and set of environmental values within the higher education community. The key areas of this charter include public outreach, environmental literacy and promising networking amongst universities. 


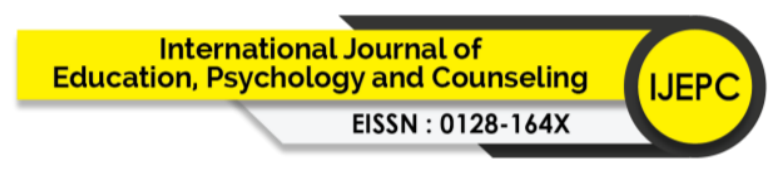

Volume 5 Issue 37 (December 2020) PP. 10-26

DOI 10.35631/IJEPC.537002

- The main discussion of Thessaloniki Declaration 1997 was on the need for radical social change prior to the environmental change. The declaration also argued that sustainability initiatives must happen at all levels of society and reflect interdisciplinary. Further, the declaration delineated the linkage of environmental sustainability with poverty, population, food security, democracy, human rights, peace and health and a respect for traditional cultural and ecological knowledge.

- In 2000, the Global Higher Education for Sustainability Partnership (GHESP) was formed to promote and incorporate sustainable development strategies into higher education institutions via curricula, research, operations outreach, and assessment and reporting. It also stressed on university collaboration, transdisciplinary and educating the educators.

- The Lüneburg Declaration 2001 called on higher learning institutions and other stakeholders to continuously evaluate and update learning resources that reflect scientific sustainability, teacher education on sustainable development, promote creative development and implementation of comprehensive sustainability projects in higher education, etc.

- The Declaration of Barcelona 2004 emphasised similar aspects of sustainability in the context of higher education, which include teaching and learning, research and outreach activities, but particularly focused on engineering education.

- The Graz Declaration 2005 imposed strong challenge and new opportunities for universities, which include offering sustainable development a fundamental status in their policies and doings, which include learning and teaching, research and internal and external social responsibility.

- The Turin Declaration 2009 presented a critical example of sustainable development, known as 4Es. It illustrated the interaction and reciprocity of economics, ethics, energy policy and ecology, encouraging a movement toward sustainability beyond natural sciences. It also stressed on fostering awareness of responsibility and ethical behaviours among learners, educators, scholars and leaders to achieve sustainability.

- The Abuja Declaration 2009 recognised the importance of university-industrygovernment linkages. It also pinpointed the role of higher education in generating knowledge and educating the leaders and educators of the future based on spirituality, ethics and morality.

The United Nations (Rio+20) created the Higher Education Sustainability Initiative (HESI) in 2012 to engage higher education institutions with a sustainable development agenda and heighten their roles in its implementation. Some of the member universities activities include executing SDGs-based campus sustainability, supporting local sustainability efforts, raising awareness on campus about the SDGs, etc. (Sustainable Development Goals Knowledge Platform Website at sustainabledevelopment.un.org/index.html).

- The 2030 Agenda, which was set in 2015 by United Nations General Assembly, delineated 17 SDGs to be achieved by the year 2030. The tertiary education sector is hoped to further mobilise this agenda, particularly, SDG 4 (inclusive and equitable quality education and lifelong learning opportunities for all) toward success by producing forward-thinking human resources and knowledge that are capable to curb complex sustainability challenges (Owens, 2017). 


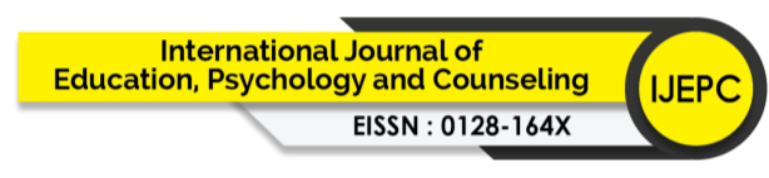

Volume 5 Issue 37 (December 2020) PP. 10-26

DOI 10.35631/IJEPC.537002

According to the aforementioned sources that are in favour of sustainability in higher education, it is plausible that a well-regulated tertiary education system can lead the societies in a nation towards pursuing sustainable development goals (Cortese, 2003). Furthermore, it is also evident that the focus on sustainability in diverse assertions gradually evolved from concentrating solely on the environmental aspect to addressing the social and economic aspects, especially in the latter statements. Moreover, the sources consistently reiterated the importance of raising awareness, educating the teachers and other stakeholders, increasing university collaborations, etc. (Lozano, et al., 2011; Wright, 2002). Such approaches are necessary for the academic community to balance the importance of the three dimensions that make up sustainable development.

Inopportunely, studies examining sustainability implementation among the signatory universities are limited and some claim that this is due to the process itself, which consumes so much time because of various challenges encountered by the universities (Holdsworth \& Thomas, 2015; as cited by Jenstrrom in Wright, 2002). On another note, Wolff, Sjöblom, Hofman-Bergholm and Palmberg (2017) observed that higher education institutions lack sustainability in practices, even though the principles and policies are in place. Furthermore, the nature of sustainability, which crosses many disciplines and different specialisations of academic staff, imposes difficulties and limitations to the integration of sustainability into the higher education institution's framework (Belkhir, 2015; Ryan, Tilbury, Corcoran, Abe \& Nomura, 2010). Such circumstance may arise due to the lack of sustainability awareness, attitudes and actions (Ibrahim et al., 2011; Sunthonkanokpong \& Murphy, 2019), and therefore an incremental approach should be embraced (Velazquez et al., 2006), thus, this study proposes to measure employees' awareness level as the initial effort.

\section{Sustainable Development Awareness}

Numerous studies asserted that one main way to reach systemic sustainability goal is by raising the awareness of sustainable development dimensions among individuals, which simultaneously carves their life paths and practices that are in line with its philosophies (Ibrahim, Osman, \& Bachok, 2011; United Nations, 2018; Atmaca et al., 2019). More specifically, several scholars highlighted a lack of sustainable development awareness as one of the main reasons for universities to resist engagement with sustainability (Lozano et al., 2011; Pena-Cerezo, Artaraz-Minon \& Tejedor-Nunez, 2019). Having said that, gauging educators' awareness on sustainability phenomena seems paramount to impart accurate and relevant knowledge to their students (Filho, Shiel, \& do Paço, 2015; Stevenson, Ferreira, Davis \& Evans, 2012) as well as to embark on other campus sustainability initiatives. Nevertheless, based on Gericke, Boeve-de Pauw, Berglund and Olsson (2018), most existing instruments that measure the knowledge, awareness or attitudes of sustainability lean towards environmental element, thus, limiting the consciousness of societal and economic dimensions, even though their roles are vital in solving environmental problems. As such, adopting an instrument that measures the awareness of complementary sets of sustainable development dimensions seems paramount and, therefore, this study espouses such approach.

Malaysia is progressively making a relevant context to sustainable development, as the country attempts to integrate the core elements of sustainability from various sources, such as Agenda 21 into most of its national policies (Saat, Jamin, Alipiah \& Khairuddin, 2018). More recently, Malaysia aspires to entrench the Agenda 2030's 17 SDGs in all facets of development as outlined in the $11^{\text {th }}$ Malaysia Plan. Corroborating its role as one of the main catalysts for the 


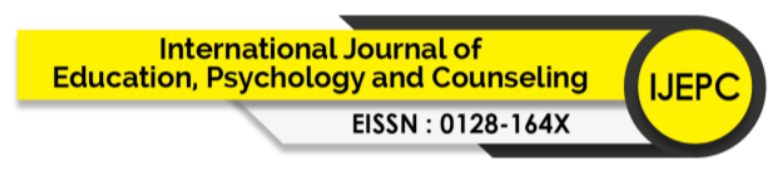

Volume 5 Issue 37 (December 2020) PP. 10-26

DOI 10.35631/IJEPC.537002

nation's sustainability efforts, the government imbues the sustainability vision into the higher education sector. As a result, many institutions began to embark on ample initiatives, which include campus sustainability policies, guidelines, operations, researches, etc. (Mohd Isa, 2016).

Meanwhile, some scholars opined that most of the existing studies in the context of Malaysia tend to focus on the environmental aspects; hence, as observed in other studies (in the previous section) lack a comprehensive stance on sustainable development (Endut, Mustapa \& Peng, 2011; Mohd Isa et al., 2018; Saadatian, Dola, Salleh \& Tahir, 2011). Further, literature investigating sustainability awareness, particularly, among academic staff or educators seems scant. To the best knowledge of the authors, such inquiry is pivotal and highly relevant to drive the country's sustainability goals as the educators are positioned to influence the students and community as a whole via teaching, researches, outreach activities and campus or nationwide policymaking (Cortese, 2003). To fill the aforementioned gaps in the literature, this study aims to gauge university educators' awareness of sustainable development dimensions. Thus, the study's research question is:

$R Q: \quad$ What is the level of sustainable development dimensions (economy, social and environment) awareness among educators in a Malaysian private university?

\section{Methodology}

\section{Sample and Data Collection Procedure}

The respondents of this study were educators of a private university in Malaysia. The sample size was determined as 169 based on Krejcie and Morgan (1970) table. The respondents were selected based on simple random sampling technique. The researchers have adopted both offline and online survey instrument, and the respondents were given one month to revert. One reminder to return the completed forms was sent to all respondents via email after two weeks of questionnaire distribution. A total of 155 (91.7\%) online and offline questionnaires were collected within the stipulated time. All 155 were identified as usable during the screening procedure and were proceeded with analysis.

\section{Measure and Analysis}

The survey instrument encompasses the following sections: Part A consists of demographic questions; and Part B consists of statements regarding sustainable development dimensions (economy, social and environmental) awareness, which were gauged using 36 items from Sustainable Development Awareness Scale (Atmaca et al., 2019). The authors (Atmaca et al., 2019) specified E1, E8, E10, EN2, EN9, EN13 as negative and EN4 as control items and they were recoded accordingly during the analysis. The respondents used a five-point Likert scale (" $1 "=$ "strongly disagree" to " $5 "=$ "strongly agree") to indicate their level of agreement or disagreement with the statements provided. 
Table 1: Reliability Test for the Scale

\begin{tabular}{ccc}
\hline Variable & Number of Items & Cronbach's Alpha \\
\hline Economy & 13 & 0.729 \\
Social & 9 & 0.913 \\
Environment & 14 & 0.621 \\
\hline
\end{tabular}

A measure's reliability is determined by testing both consistency and stability. Cronbach's coefficient alpha (Cronbach, 1946) is the most common method to test reliability. For this study, the test was conducted in SPSS statistical software, version 23 and was calculated based on sub-dimensions of the scale (economy, social and environment). Cronbach's alpha coefficient portrayed in Table 1 is ranging from .621 to .913. Sekaran and Bougie (2016) suggested that the reliability above .60 is within the acceptable range. Hence, this study is considered as acceptable to test the awareness of sustainable development.

\section{Findings and Discussion}

\section{Sample Profile}

This section outlines the results of the study. The analysis of the data was performed using SPSS statistical software, version 23. In part A of the questionnaire, the respondents were asked to provide demographic details. Table 2 depicts the demographic profile of the respondents $(n=155)$ participated in the research study.

Table 2: Demographic Profile of the Respondents

\begin{tabular}{llcc}
\hline Profile of Respondents & Frequency & $\begin{array}{c}\text { Percentage } \\
(\boldsymbol{\%})\end{array}$ \\
\hline Gender: & Male & 58 & 37.42 \\
Age: & Female & 97 & 62.56 \\
& $20-30$ & 10 & 6.45 \\
& $31-40$ & 85 & 54.84 \\
& $41-50$ & 48 & 30.97 \\
& $>50$ & 12 & 7.74 \\
Position: Assist & & \\
Lecturer/Tutor & 22 & 14.19 \\
& Lecturer & 82 & 52.90 \\
& Senior Lecturer & 42 & 27.10 \\
& Assoc. Prof & 4 & 2.56 \\
Others & 5 & 3.23 \\
Income: & $<4000$ & 19 & 12.26 \\
& $4001-6000$ & 57 & 36.77 \\
& $6001-8000$ & 47 & 30.32 \\
8001-10000 & 25 & 16.13 \\
>10000 & 7 & 4.52 \\
1-3 years & 11 & 7.10 \\
4-6 years & 30 & 19.35 \\
7-9 years & 33 & 21.29 \\
\hline
\end{tabular}




\begin{tabular}{cccc}
\hline & 10-14 years & 46 & 29.66 \\
Area: & E15 years & 35 & 22.58 \\
& IT & 39 & 25.16 \\
& Arts \& Langering & 39 & 25.16 \\
& 8 & 5.16 \\
Business/Mgmt/Acc. & 53 & 34.19 \\
Law & 10 & 6.45 \\
Others & 6 & 3.87 \\
\hline
\end{tabular}

As presented in Table 2, the gender distribution of the respondents consisted of $62.6 \%$ female and $37.4 \%$ male. Most (54.8\%) of the respondents were within the age group of 31 to $40,31.0 \%$ were between 41 to 50 age group, $7.7 \%$ were 50 years old and above and the remaining $6.5 \%$ were between 21 and 30 years old. Out of 155 respondents, $82(52.9 \%)$ of them were lecturers and $42(27.1 \%)$ were senior lecturers. Rest of them were associate or assistant professors $(2.6 \%)$, assistant lecturers or tutors $(14.2 \%)$ and remaining were others $(3.2 \%)$. In terms of income level, majority (36.7\%) of them fell under RM4, 001 to RM6, 000 range and for the number of years in service, most of the respondents $(29.66 \%)$ were working in the specified university for at least 10 to 14 years. However, $22.5 \%$ of the educators were attached to the university for more than 15 years. Most of the respondents (34.2\%) for this study were from the business, management and accounting backgrounds, $25.2 \%$ were from information technology, 25.2\% were from engineering and the rest were from law and other backgrounds.

$R Q:$ What is the level of sustainable development dimensions (economy, social and environment) awareness among educators in a Malaysian private university?

Table 3: Results for Awareness of Economic, Social and Environmental Dimensions

\begin{tabular}{lccccc}
\hline Items & Mean & SD & Disagree $(\%)$ & Neutral (\%) & Agree (\%) \\
\hline E1 & 3.374 & 1.1686 & 28.39 & 21.94 & 49.68 \\
E2 & 4.206 & .7270 & 2.58 & 8.39 & 89.03 \\
E3 & 3.987 & .7024 & 1.94 & 19.35 & 78.71 \\
E4 & 4.110 & .7860 & 3.23 & 14.19 & 82.58 \\
E5 & 4.323 & .6440 & 0.00 & 9.68 & 90.32 \\
E6 & 4.265 & .6939 & 0.65 & 12.26 & 87.10 \\
E7 & 4.303 & .7151 & 0.65 & 12.90 & 86.45 \\
E8 & 2.839 & 1.3166 & 47.74 & 21.94 & 30.32 \\
E9 & 4.103 & .6662 & 1.29 & 11.61 & 87.10 \\
E10 & 2.335 & .7918 & 59.35 & 34.19 & 6.45 \\
E11 & 3.994 & .6885 & 1.94 & 18.06 & 80.00 \\
E12 & 4.129 & .6714 & 1.29 & 12.90 & 85.81 \\
E13 & 4.271 & .6478 & 1.29 & 7.10 & 91.61 \\
S1 & 4.445 & .7130 & 1.29 & 7.10 & 91.61 \\
S2 & 4.323 & .7111 & 0.65 & 10.32 & 89.03 \\
S3 & 4.245 & .7057 & 0.00 & 15.48 & 84.52 \\
S4 & 4.452 & .6664 & 0.65 & 7.74 & 91.61 \\
S5 & 4.535 & .5842 & 0.00 & 4.52 & 95.48 \\
S6 & 4.387 & .6968 & 0.65 & 10.32 & 89.03
\end{tabular}




\begin{tabular}{lccccc} 
S7 & 4.303 & .7060 & 0.65 & 12.26 & 87.10 \\
S8 & 4.232 & .7281 & 0.00 & 17.42 & 82.58 \\
S9 & 4.355 & .6002 & 0.00 & 6.45 & 93.55 \\
EN1 & 4.316 & .6320 & 0.65 & 7.10 & 92.26 \\
EN2 & 2.755 & 1.0278 & 41.94 & 35.48 & 22.58 \\
EN3 & 3.942 & .7749 & 3.87 & 21.29 & 74.84 \\
EN4 & 4.206 & 0.6809 & 1.29 & 10.97 & 87.74 \\
EN5 & 4.245 & .7503 & 2.58 & 10.97 & 86.45 \\
EN6 & 4.413 & .7097 & 0.65 & 10.97 & 88.39 \\
EN7 & 4.361 & .7635 & 1.29 & 9.68 & 89.03 \\
EN8 & 3.419 & 1.2107 & 21.94 & 23.87 & 54.19 \\
EN9 & 1.677 & .6540 & 89.68 & 10.32 & 0.00 \\
EN10 & 4.400 & .6800 & 0.65 & 9.03 & 90.32 \\
EN11 & 4.348 & .7080 & 1.29 & 7.74 & 90.97 \\
EN12 & 2.452 & 1.3920 & 63.87 & 9.03 & 27.10 \\
EN13 & 4.329 & .7482 & 1.29 & 10.97 & 87.74 \\
EN14 & 4.058 & .8697 & 4.52 & 19.35 & 76.13 \\
\hline
\end{tabular}

The results summarised in Table 3, are based on the answers obtained from the survey. The data in Table 3 shows that all mean scores for the items that measure the awareness of sustainable development were above 2.5, except for $\mathrm{E} 10$ ( $\mathrm{M}=2.335$, economic dimension) and EN9 ( $M=0.1677$, environmental dimension). The results showing a mean score of above 2.5 revealed that majority of the respondents are aware of sustainable development and its dimensions. The standard deviation ranges from 0.584 to 1.392 . Among the three dimensions, the items related to the social dimension are most highly agreed, $(82.58 \%$ to $95.48 \%)$ by the respondents. It indicates the highest level of awareness pertaining to sustainability dimension among educators working in the university compared to other dimensions.

Additionally, Table 3 also presents the level of awareness of sustainable development among respondents in terms of percentages. For the economic dimension, most of the participants of the survey have agreed to all the statements except for E1, E8 and E10. Ten out of the thirteen items for this dimension were agreed (78.71\% to $91.61 \%)$ by the respondents, reporting a high level of awareness. For E1 (individuals should shop in the direction of their desires without regards to their needs) and E8 (livestock, agricultural and industrial production should be focused on applications that will generate high profit in the short term), majority of the respondents answered 'neutral' to 'agree'. Furthermore, for E10 (for economic development, non-production sectors should be emphasised), 59.35\% of respondents did not agree with the statement. Such responses suggest that some respondents may lack understanding of specific terms or phrases pertaining to economic sustainability or simply have never been exposed to the concepts (Sheikh, Aziz \& Yusof, 2012). In addition, different disciplines and specialisations of the respondents may have also contributed to these results (Belkhir, 2015; Ryan, et.al, 2010). Hence, personal initiatives (such as formal or informal learning) and organisational efforts (such as training, managerial support and consultancy), focusing on relevant sustainability aspects and concepts seem vital to induce significant understanding and awareness among educators (Said, Yahaya \& Ahmadun, 2007; Casey \& Sieber, 2016).

From the answers obtained for the environmental dimension, 11 out of 14 items scored more than $54.19 \%$ (lowest) to $92.26 \%$ (highest) signifying that most of the respondents agreed with 


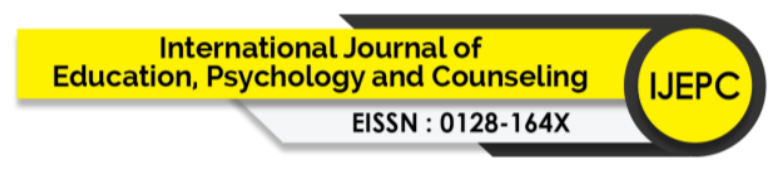

Volume 5 Issue 37 (December 2020) PP. 10-26

DOI 10.35631/IJEPC.537002

the statements. Surprisingly, for EN9, there was $0 \%$ agreement on the statement (to leave a greener world for future generations, responsibility for afforestation and the protection of the trees is the responsibility of each individual) indicating that the respondents did not agree that afforestation and the protection of the trees is part of individual responsibility. Wahida, Hamidi and Tuan (2004) obtained a similar result and the authors have pointed out that the society has increased knowledge of environmental concerns and recognition of the need to protect the atmosphere, but the degree of individual involvement is still poor. It might be one of the reasons for the respondents to completely disagree with the statement. Meanwhile, for EN2 (the use of public transportation at short distances does not help to maintain atmospheric equilibrium), majority have answered 'neutral' (35.48\%) to 'agree' (28.58\%) and for EN12, 63.87\% of the respondents did not agree with the statement (I think global warming poses a serious threat to the future of our world if caution is not taken). The disagreements for certain items could have resulted from cultural differences and factors that may have affected the responses to awareness of sustainable development. Sunthonkanokpong and Murphy (2019) posited that it is always important to consider cultural differences when addressing sustainable development dimensions as certain factors might be less significant than others depending on the countries. As the results indicate 29 out of the 36 items rated as "agreed" (above 70\%), it can be concluded that the educators working in the university have a high-level of sustainable development dimensions awareness.

Findings for the research question showed the highest percentage of awareness level in the social dimension, followed by economic and environmental dimensions. In spite of the ample attention that the environmental facet has been receiving from various literature and community practices, these results impose a contrast to this view. The study of Pena-Cerezo et al. (2019) also observed congruent results, where the consciousness level for sustainable consumption among Spanish university's undergraduates was highest in the social dimension, followed by economic and environmental aspects. In relation to these contradictory outcomes, the authors deduced that the inclination to consider the environment as the dominant sustainability dimension is becoming increasingly antiquated. However, the authors reaffirmed that to pursue a systemic sustainable development, a balanced awareness among these dimensions should transpire, instead of one superseding the rest. In fact, the Agenda 2030 (United Nations, 2015; United Nations, 2018) and many other aforementioned sustainability frameworks, as well as scholars, indorse such deportment. Hence, universities should look into integrating all three vital traits (social, economy and environment) of sustainability into their educators' training, workshops, or any relevant activities and policies that would facilitate an equivalent awareness of sustainability dimensions.

\section{Conclusion}

Sustainable development is an imperative constituent in the tertiary education system of any nation, including Malaysia. This study, in particular, contributes to the literature on the relevance of embracing a comprehensive sustainability attitude, comprising the economic, societal and environmental dimensions. It also notably focuses on the grassroots efforts of campus sustainability, which is to measure the three dimensions of sustainable development awareness among educators. Such exploration seems vital prior to venturing into more major initiatives, such as curriculum development, teaching and learning, as the lack of awareness may encumber the subsequent activities. Thus, the results obtained from this research will be of interest and useful to the management of the university and other higher learning institutions to better plan and design their sustainability initiatives across all areas. In fact, the results 


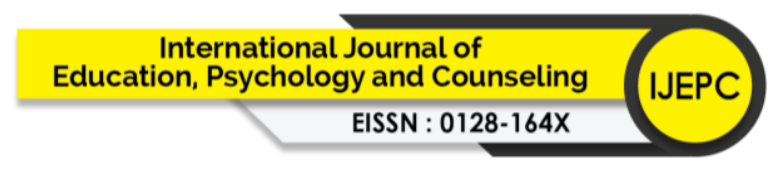

Volume 5 Issue 37 (December 2020) PP. 10-26

DOI 10.35631/IJEPC.537002

revealed the misconception, which is the tendency to assume most individuals are aware of the environmental aspects as opposed to economic and social dimensions. However, several limitations in this study need to be taken into account. First, the demographics of this study are not representative of the general population, thus the results may not be able to provide a generalised view. Secondly, the targeted participants (educators) are only limited to one private university in Malaysia and therefore, the outcomes may not be demonstrative across regions and universities. Hence, future research may look into incorporating the whole of Malaysia's higher education sector to improve the conclusion of the findings.

\section{References}

Atmaca, A.C., Kiray, S. A., \& Pehlivan, M. (2019). Development of a measurement tool for sustainable development awareness. International Journal of Assessment Tools in Education. 6(1), 80-91. https://dx.doi.org/10.21449/ijate.518099.

Belkhir, L. (2015). Embedding sustainability in education through experiential learning using innovation and entrepreneurship. Higher Education Studies, 5(1), 73-80. https://doi.org/10.5539/hes.v5n1p73.

Böhringer, C. \& Jochem, P. E. P. (2007). Measuring the immeasurable - a survey of sustainability indices. Ecological Economics, 63(1), 1-8. https://doi.org/10.1016/j.ecolecon.2007.03.008

Casey, D. \& Sieber, S. (2016). Employees, sustainability and motivation: Increasing employee engagement by addressing sustainability and corporate social responsibility. Research in Hospitality Management. 6(1), 69-76. doi: 10.2989/ RHM.2016.6.1.9.1297

Centre for Environment Education. (2007). Sustainable development: an introduction. Internship Series, 1, 2-36. Retrieved from http://www.sayen.org/Volume-I.pdf

Cheong, I. P.A. (2010). Educating pre-service teachers for a sustainable environment. AsiaPacific Journal of Teacher Education, 33(1), 97-110. https://doi.org/10.1080/1359866052000341151

Cortese, A. D. (2003). The critical role of higher education in creating a sustainable future. Planning for Higher Education, 31(3), 15-22.

Cronbach, L. J. (1946). Response sets and test validity. Educational and psychological measurement, 6(4), 475-494.

Dhar Chakrabarti, P. G. (2017). People, planet, and progress beyond 2015. New Delhi: The Energy and Resources Institute (TERI). Retrieved from https://books.google.com.my/books?id=e4fvDQAAQBAJ\&printsec=frontcover\&sour $\mathrm{ce}=\mathrm{gbs} \_\mathrm{ge} \_$summary_r$\& \mathrm{cad}=0 \# \mathrm{v}=$ onepage $\& \mathrm{q} \& \mathrm{f}=$ false.

Endut, A. F., Mustapa, S. I., \& Peng, L. Y. (2011). Role of knowledge institution in achieving sustainable development: UNITEN experience. 15th International Conference on ISO \& TQM (15-ICIT), 26-28 July. Retrieved from http://www/uniten.edu.my/newhome/content_list. asp?ContentID=4505.

Elkington, J. (1997). Cannibals with forks: the triple bottom line of 21st century business. Capstone, Oxford.

Filho, W.L, Shiel,C. \& do Paço, A. (2015). Integrative approaches to environmental sustainability at universities: An overview of challenges and priorities. Journal of Integrative Environmental Sciences, 12(1), 1-14. https://doi.org/10.1080/1943815X.2014.988273

Fisher, P. \& McAdams, E. (2015). Gaps in sustainability education. International Journal of Sustainability in Higher Education, 16(4), 407-423. https://doi.org/10.1108/IJSHE-082013-0106. 


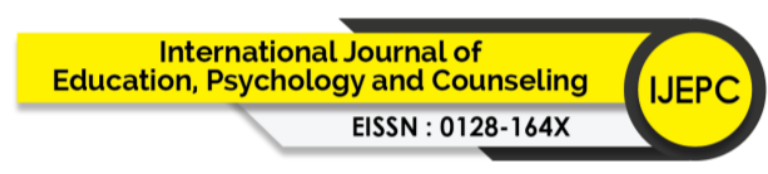

Volume 5 Issue 37 (December 2020) PP. 10-26

DOI 10.35631/IJEPC.537002

Gericke, N., Boeve-de Pauw, J., Berglund, T. \& Olsson, D. (2018). The sustainability consciousness questionnaire: The theoretical development and empirical validation of an evaluation instrument for stakeholders working with sustainable development. Sustainable Development, 27(1), 35-49. DOI: 10.1002/sd.1859

Goodwin, N. R. (2003). Five kinds of capital: useful concepts of sustainable development. In Global Development and Environment Institute, Working Paper, Tufts University, September 2003, USA. Retrieved from http://www.ase.tufts.edu/gdae/publications/working_papers/0307sustainabledevelopm ent.PDF.

Heinberg, R. (2010). What is sustainability? The Post Carbon Reader Series: Foundation Concepts. $\quad$ Retrieved from https://cdn.auckland.ac.nz/assets/arts/documents/What\%20is\%20Sustainability.pdf

Holdsworth, S. \& Thomas, I. (2015). Framework for introducing education for sustainable development into university curriculum. Journal of Education for Sustainable Development, 9(2), 137-159. https://doi.org/10.1177/0973408215588246

Ibrahim, A.N. Osman, M.M. \& Bachok, S. (2011). The level of awareness towards environmental issues and concern among students in tertiary level: Case study of universities students in Kuala Lumpur and Klang Valley of Malaysia. In: 11th International Congress of Asian Planning Schools Association (APSA 2011) , 19-21 September 2011, University of Tokyo Hongo Campus, Tokyo, Japan. Retrieved from http://irep.iium.edu.my/3378/1/apsa_japan_environment310511.pdf

Mohd Isa, N.K.M. (2016). Sustainable campus and academic staffs awareness and behaviour in Malaysia's institutions of higher learning: A case study of UPSI. Geografia. Malaysian Journal of Society and Space. 12(6). 89-99. Retrieved from http://ejournals.ukm.my/gmjss/article/view/18023/5628

Mohd Isa, N.K., Mohd Yunos, M.Y., Ismail, K., \& Marzuki, M. (2018). Sustainability goals and project success from the perspective of the stakeholders of green building project in Malaysia: A preliminary study. Perspektif. Jurnal Sains Sosial Dan Kemanusiaan, 10(1), $\quad 21 \quad$ - $\quad 32 . \quad$ Retrieved from http://ojs.upsi.edu.my/index.php/PERS/article/view/1778

Kollmair, M., \& St. Gamper, J. (2002). The sustainable livelihoods approach. Input Paper for the Integrated Training Course of NCCR North-South Aeschiried, 9-20 September 2002, Switzerland. Retrieved from http://www.alnap.org/pool/files/sla-gamperkollmair.pdf.

Krejcie, R.V. \& Morgan, D. W. (1970). Determining sample size for research activities. Educational and Psychological Measurement. 30. 607-610. Retrieved from https://home.kku.ac.th/sompong/guest_speaker/KrejcieandMorgan_article.pdf

Lawn, P. A. (2001). Toward sustainable development: An ecological economic approach. CRC Press: Florida.

Lozano, R., Lukman, R., Lozano, F.J., Huisingh, D. \& Lambrechts, W. (2011). Declarations for sustainability in higher education: becoming better leaders, through addressing the university system, Journal of Cleaner Production, 1-10. doi: 10.1016/j.jclepro.2011.10.006.

Munasinghe, M. \& Shearer, W. (1995). Defining and measuring sustainability: The biogeophysical foundations. United States.

Munasinghe, M. (2010). Sustainomics Framework. In Making development more sustainable: Sustainomics framework and practical applications. (32-75). Retrieved from http://www.mohanmunasinghe.com/pdf/Sust-SecEd-Ch02-SustFram-v6rF-S.pdf 


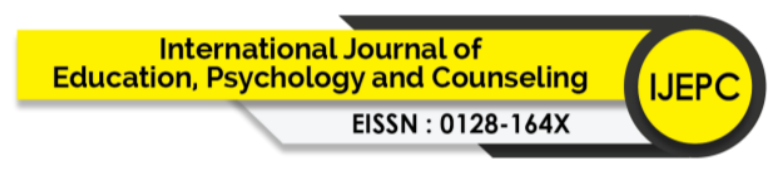

Volume 5 Issue 37 (December 2020) PP. 10-26

DOI 10.35631/IJEPC.537002

Owens, T.L. (2017). Higher education in sustainable develeopment goals framework. European Journal of Education: Research, Development and Policy, 52 (4), 414-420. https://doi.org/10.1111/ejed.12237.

Pena-Cerezo, M. A., Artaraz-Minon, M. \& Tejedor-Nunez, J. (2019). Analysis of the consciousness of univesity undergraduates for sustainable consumption. Sustainability. 11(17). 4597. https://doi.org/10.3390/su11174597

Purvis, B., Mao, Y. \& Robinson, D. (2019). Three pillars of sustainability: In search of conceptual origins. Sustainability Science, 15, 681-695. https://doi.org/10.1007/s11625-018-0627-5.

Ryan, A., Tilbury, D., Corcoran, P., Abe, O. \& Nomura, K. (2010). Sustainability in higher education in the Asia-Pacific: Developments, challenges, and prospects. International Journal of Sustainability in Higher Education, 11(2), 106-119. https://doi.org/10.1108/14676371011031838

Saadatian, O., Dola, K., Salleh, E., \& Tahir, O. M. (2011). Identifying strength and weakness of sustainable higher educational assessment approaches. International Journal of Business and Social Science, 2(3), 137-146. Retrieved from http://ijbssnet.com/journals/Vol._2_No._3_\%5BSpecial_Issue__January_2011\%5D/16.pdf

Saat, S.A., Jamin, R.M., Alipiah, R.M. \& Khairuddin, N.I.M. (2018). Transformation the role of government in solid waste management in Malaysia through Local Agenda 21 (LA21). Indian Journal of Public Health Research \& Development, 9(12). 2690-2695. doi:10.5958/0976-5506.2018.02154.X

Said, A.M., Yahaya, N. \& Ahmadun, F.R. (2007). Environmental comprehension and participation of Malaysian secondary school students. Environmental Education Research, 13(1). 17-31, doi: 10.1080/13504620601122616

Sekaran, U., \& Bougie, R. (2016). Research methods for business: A skill building approach. John Wiley \& Sons.

Sheikh, S.N.S, Aziz, A.A. \& Yusof, K. M. (2012). Perception on sustainable development among new first year engineering undergraduates. Social and Behavioral Sciences. 56. 530-536. doi: 10.1016/j.sbspro.2012.09.685.

Stevenson, R., Ferreira, J.A., Davis, J. \& Evans, N. (2012). Embedding EfS in teacher education: An introductory guide to using the systems change model. Sydney, Australia: Office for Teaching and Learning. Retrieved from https://eprints.qut.edu.au/67598/1/ID11-1900_Embedding_EfS_Guide_2014.pdf

Sunthonkanokpong, W. \& Murphy, E. (2019). Sustainability awareness, attitudes and actions: A survey of pre-service teachers. Issues in Educational Research, 29(2). 562-582. Retrieved from http://www.iier.org.au/iier29/sunthonkanokpong.pdf

Tilbury, D. (2011). Higher education for sustainability: a global overview of commitment and progress. In GUNI (Ed.), Higher Education in the World 4. Higher Education's Commitment to Sustainability: From Understanding to Action (pp. 18-28). Barcelona: GUNI. Retrieved from http://blogs.bournemouth.ac.uk/research/2012/02/03/latest-unglobal-report-on-he-for-sustainability/.

United Nations General Assembly. (2015). Transforming our world: The 2030 agenda for sustainable development". United Nations - Sustainable Development Goals Knowledge Platform. Retrieved from https://sustainabledevelopment.un.org/content/documents/21252030\%20Agenda\%20f or\%20Sustainable\%20Development\%20web.pdf 


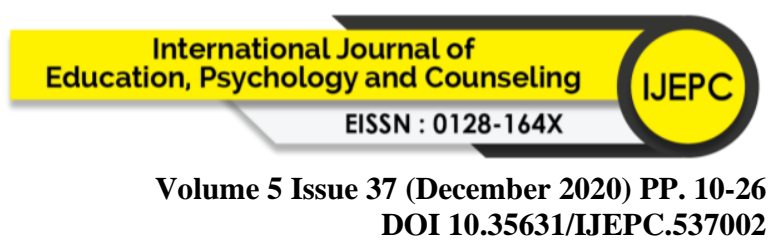

United Nations. (2018). The Sustainable Development Goals Report. Retrieved from https://unstats.un.org/sdgs/files/report/2018/TheSustainableDevelopmentGoalsReport 2018-EN.pdf

Velazquez, L., Munguia, N., Platt, A., \& Taddei, J. (2006). Sustainable university: what can the matter be? Journal of Cleaner Production, 14(9-11), 810-819. doi:10.1016/j.jclepro.2005.12.008.

Venuste, N., Olivier, H. \& Valens, N. (2017). Knowledge, attitudes and awareness of preservice teachers on biodiversity conservation in Rwanda. International Journal of Environmental and Science Education, 12(4), 643-652. https://files.eric.ed.gov/fulltext/EJ1144760.pdf

Villeneuve, C., Tremblay, D., Riffon, O., Lanmafankpotin, GY., \& Bouchard, S. (2017). A systemic tool and process for sustainability assessment. Journal of Sustainability, 9(10), 1909, https://doi.org/10.3390/su9101909

Wahida, A., Hamidi, I., \& Tuan, R. S. H. (2004). Sokongan dan penglibatan masyarakat ke arah pemantapan pengurusan alam sekitar mampan. In Seminar Kebangsaan Geografi dan Alam Sekitar. Bangi: Universiti Kebangsaan Malaysia.

Wolff, L-A., Sjöblom, P., Hofman-Bergholm, M. \& Palmberg, I. (2017). High performance education fails in sustainability? - A reflection on Finnish primary teacher education. Education Sciences, 7(32). https://doi.org/10.3390/educsci7010032

Wright, T. S. A. (2002). Definitions and frameworks for environmental sustainability in higher education. Higher Education Policy, 15, 105-120. Retrieved from http://158.132.155.107/posh97/private/environmental-management/definitionsustainability-Wright.pdf 